\title{
Technology-integrated Mathematics Education: A Facilitating Factor to Enrich Learning
}

\author{
Hamdi Serin (Corresponding author) \\ Department of Mathematics Education, Ishik University \\ Erbil 44001, Iraq \\ E-mail: hamdi.serin@ishik.edu.iq
}

Received: October 30, 2017 Accepted: November 27, 2017 Published: December 4, 2017

doi:10.5296/ijld.v7i2.12082ＵRL: https://doi.org/10.5296/ijld.v7i2.12082

\begin{abstract}
The potential of technological devices to enrich learning and teaching mathematics has been widely recognized recently. It goes without saying that when technology is integrated into teaching practice. Students` learning of mathematics is significantly promoted. This paper highlights that the availability of technological devices, teacher beliefs, easy access to resources and most importantly teacher skill of using technological devices effectively are decisive factors that can provide learners better understanding of mathematical concepts.
\end{abstract}

Keywords: technology, mathematics, teaching, learning 


\section{Technology-Aided Instruction}

In the recent years, most of the developed countries have started to use technology-contained courses in their education programs. It has been necessary that technological devices, that will facilitate the life, must be given deserved place within the school and technology-literacy must be given through the courses.

Evaluating the situation from the perspective of mathematics education, it can be very basically said that students should use computer in the mathematic calculations very easily; teachers should make use of it as a demonstration tool and generate enhanced learning mediums; the computer must be both a part of individual studies and group works as well; and the most important of all, students should use the computer as a device in the solution of the problems and in the production and process of information (Agyei, Agvei \& Voogt, 2011; Baki, 1996).

Generally speaking, technology-aided teaching and education means that the communication and information technologies take place in the process of any type of education (Alshehri, 2014). Technology might have different roles and impacts on this process. Not only is it used as a canal in the transmitting information to the students but it can be also used as a cognitive device that will ease cognitive burdens of the students in the process of information. Additionally, it can be used as an administrative tool for the operations like keeping records of the students and providing communication between school, institution and family. In the constructivist education and teaching, besides technology is made use of being barely a simple educative and/or teaching tool, technology is used as a device that will provide assistance for reaching at the data and information in a very fast way and the organization and analysis of the information. According to Özden (2002), technology-aided education is defined as an individual or community device of implementation that everybody can proceed according to the level of personal perception and comprehension of knowledge and it is applied by using the materials of the courses for providing opportunity to get education in the most suitable time and place for themselves; it is also accessed over Computer and its network (LAN, Intranet, Internet); it has multimedia features and prepared in interaction with pedagogical characteristics; it does not only transmit the information and data but also it tries to give skill.

In addition, the application of technology in the mathematics education [in most of the countries] has recently started, there are very significant findings about the impact of technology support on mathematics education and teaching. Thus, it is inevitably required to make radical changes to be able to provide much more effective and beneficial teaching in Mathematics (Memişoğlu, 2005).

In a literature review by Koç (2004), it has been revealed that the use of technology as a teaching tool in a useful and effective way that make significant changes in the success, attitudes, and relationships of the students with their friends and teachers and it may develop high level of thinking skill.

Evertson and Weinstein (2006) have stressed in their handbook of class management 
depending on the analysis of the latest researches and theories that class management researches are gathered under four themes. One of them is that the basic condition of preparing a useful and positive teaching medium is the determination of the characteristics of the students (like demographic information, interests and needs, sensitive and psychological peculiarities) by the teacher and the arrangement of the class management implementation as parallel to this determination. Accordingly, it is searched for the effects of the technology-aided education on the characteristics of students that affect the class management in this study.

In the following parts, it has been put emphasis on the characteristics of students as dependent variables and the effects of those in the class management.

In the study on smartboards that has been held in England by Jones (2004), it has been mentioned that the use of technology does not contribute alone to the comprehension of the subjects and in-class discipline. It has been emphasized that the role of teacher is very significant in parallel to well-designed software with technology and a well-prepared course. In the courses, a teacher-centered implementation has been run and it has been shown that this implementation is more effective for students' comprehension and earning process. In the study, students have been presented how to solve whole number problems. The students are divided into two groups and called to the board where making operations have been provided by games via the software used.

Information and communication technologies have been widely used in our daily lives and surroundings for a long time. However, there is no still a consensus on how to apply these technologies and for the Mathematics courses at schools. Investigating the literature, it is seen that there are some ideas regarding some prejudices on the use of calculation in the mathematics and even some views saying it is harmful (Baki, 2002).

Talking about the computer-supported medium, it is seen that the perspectives are positive and the expectations are much higher. The reason for high expectations is possibly because technology has facilitated the works in the most fields. However, it is required to arrange four dimensions, the components forming each dimension synchronically and harmoniously and to consider together each dimension and their components in investment programs. These four dimensions are investment, hardware-software, teacher training and maintenance-care. The hardware will be useless and worthless without software and hardware and software will mean nothing without maintenance and care; and above all, it is evident that if the teacher is not trained, none of them will be used effectively.

New needs and requirements have appeared due to the support of Mathematics teaching and education with technology. Nevertheless, it is still a matter of debate how and in what way the technology will be utilized in education to help them improve their achievement (NCTM, 2000).

Definition of education has been made in different ways in the literature; for instance, it is described as the process in which the individuals bring forth to intentional changes in their attitudes through their own lives (Ertürk, 1982). Baki (2008) defined learning as the process 
of attitude change by the individual. Also, it can be specified as the permanent-traced transformation in the behaviors and knowledge as a result of interaction of the individual with the environment (Özdemir et.al, 2008). Teaching is the whole process covering the improvement and development of the target behaviors and acquisition of learning (Ekici, 2008). Teaching is also called as a serial of events that are provided to learn (Baki, 2008).

Education has numerous functions several of which are to transform the individuals into the persons who can meet the needs of the society and to make them gain the knowledge/information and skills in accordance with the requirements of modern age.

Today in which the information is renewed produced in a fast way, it has showed up that it is required to access and use the information; to give the skills of info-production; to make learners adapt the lifelong learning philosophy; to give education depending not on memorizing but creating, developing and configuring the information beside the acquisition of information and skills. Together with advanced technology and age, conventional teaching methods in which the teacher used to be active have replaced with the approaches that are supported with technological tools; force students to think and question and lead to produce new information (Sarı \& Karalar, 2007).

Technological changes have been in an ongoing process since the existence of human. Everything, from using the paper in education, invention of ink, to usage of blackboards and etc., is technology. Any type of tool which is used to produce, apply, and distribute the information can be named as information technology. The changes in the science and technology have started a new era. The most important characteristics of this age which is mostly called as Information Age is that the information technologies are used densely and the information has gained importance instead of substantial and concrete productions (Akkoyunlu, 1998). The improvement of information technologies and the increase of information are connected to each other. The information increases by means of the information technologies providing the collection, protection and extension of data; it becomes prerequisite to use information technologies to be able track information in manner of permanent change. The importance and contributions of computer for the information technologies cannot be ignored. Parallel to the extension of Internet, the efficiency of computers has shown much more increase. This circumstance has given an inevitable place to the computers in the education system in which the information is transferred. As the demand for education has risen; the amount of students and data has increased; the content to be learnt gets more complicated and individual education and training has gained importance, the applications of Computer Supported Education has become a need (Odabaş1, 2012). It has become a necessity for today's communities to use information technologies, in other words teaching technologies, in teaching-training activities. As for the computers that hold the most important location among other teaching technologies, they bear the focal point in the teaching activities (Sarı \& Karalar, 2007).

The aims of using computer technologies in education can be located under two groups: The first one is the awareness of students about computers and ability to use them as a device and the second is their support for teaching and education (Aşkar, 1992). Because of the 
conventional approaches, CSE (Computer Supported Education) is perceived that teacher gives any course by using computer. Another opinion about CSE desires to see that computer is not only a device of teaching but a learning tool in the hands of students as well (Baki, 2002). The use of teaching materials for the courses has gained a very different dimension together with the adoption of structuralism as the philosophical basis of teaching program.

As guessed by many scholars, significant changes have merged in mathematics education by means of the fact that computer is not a tool in the classrooms that merely transmits data but with which students (will) set up their own information and make (Papert, 1980, DiSessa, 1990, Hoyles, 1992; Adapted from Baki, 1996). Cradler, et al (2001) have mentioned in their researches and examinations that they have reached the consequence that technological devices, electronic information and communication sources develop high level skills. Some examples related with the didactic use of computer can be given as practices-repetitions, simulations, one-to-one teaching, systems based on dialogues, didactic games, problem solving, computer-controlled experiments, information and communication mediums (Aşkar, 1992).

In the end of the 1950s, computer was used with the administrative aims in the advanced universities like Stanford and Illinois in the United States of America. (Odabaş1, 2012). In 1960s, computers were used with teachers and students in limited numbers at schools (Akkoyunlu, 1998). During the mid of 1960s and the first mid of 1970s, the number of institutions which have computers increased a lot as parallel to the emergence of low-cost computers (Altınkaya, 1998). Affected by the computer-aided education projects having been held in America, England, France and Federal Germany started studies on computer-supported education in 1970s (Odabaş1, 2012). There have been studies about using new information technologies in the primary education within European countries since 1970s (Kaya, 1998). Computer has become a device that develops in a rapid speed and used a lot; it has caused various changes and consequences by affecting the learning process.

Getting rid of school-teacher-student triangle, education has turned into a multi-channeled and dimensional education model by means of recent technologies (Oğuz, et. al 2004, s. 21; Adapted from Yildizhan, 2013). One of the development of information technologies and the effects of these developments on educational technologies is start to use smart boards in the classes.

Smart Board is set on a structure that the shared screen can be seen by everybody in education medium and the teacher makes his/her presentation by interaction with this vision (Açıkgöz \& Ateş, 2013). Interactive board is a tool of course that provides opportunity for teachers and students, by transferring generally computer screen to another monitor or LCD panel, to interfere with the operations on the screen, to make changes and to save the desired data (Bayrak, 2012).

Smart Boards can be summarized as the white board structures that provide screen sharing with class; provide opportunity for interaction with computer during teaching/learning process; and include software to transform this interaction to teaching/learning process (Açıkgöz \& Ateş, 2012). No matter how much it reminds computers and projectors from the 
point of view of using, indeed, it has more functions than those if it used accurately and effectively (Adigüzel, et al, 2011).

Interactive board activities have a positive impact on the persistency and permanence of learning due to the fact that they provide multi-perceptions such as seeing the objects from different angles, watching, listening, moving and touching and requiring the use of psychomotor skills (Smith, et., al, 2005; Çelik \& Atak, 2012).

In the $21^{\text {st }}$ century, technology is not important tool for mathematics education and all schools and educational institutions must provide students' access to technology (NCTM, 2008).

In their studies aiming at finding out the contribution of interactive boards to teaching process, Baydaş, et al (2011) has interviewed with 7 teachers who use interactive boards in the process of teaching-learning. In conclusion of the research, it has been seen that the lessons can be saved and visual elements, written texts and animations can be used more effectively by means of these boards.

\section{Conclusion}

The use of technology in education facilitates production and process of in formation in the mathematics classroom. Technological devices have the potential to change attitudes of students forwards mathematics learning and bring about success. Moreover, these tools highly contribute to interests of students in learning; thus desire and motivation of students increase in the classroom. Teacher can make a difference in learning through implementing technological devices for that reason it has become a strong need to employ their tools in teaching mathematics. It is teachers' primary responsibility to increase the effectiveness of teaching in the classroom and technology aided instruction can help teachers increase efficiency.

\section{References}

Açıkgöz, M., \& Ateş, V. (2013). Avantaj ve dezavantajlart ile akıllı tahta sistemlerine bakış. Retrieved on 07 July 2013 from http://ab.org.tr/ab13/bildiri/4.pdf.

Adıgüzel, T., Gürbulak, N., \& Sarıçayır, H. (2011). Akıllı tahtalar ve öğretim uygulamaları. Mustafa Kemal Üniversitesi Sosyal Bilimler Enstitüsü Dergisi, 8(15), 457 - 471.

Agyei, D., Agvei, D., \& Voogt, J. (2011). ICT use in the teaching of mathematics: Implications for professional development of pre-service teachers in Ghana. Education and information technologies. Education and information technologies, 16(4), 423-439. https://doi.org/10.1007/s10639-010-9141-9

Akkoyunlu, B. (1998). Bilgisayar ve eğitimde kullanılması. In B. Özer. (Eds.), Çağdaş Eğitimde Yeni Teknolojiler (pp.1-12), Eskişehir: Anadolu Üniversitesi Yayınları.

Alshehri, Z. (2014). Integrating Technology into Mathematics Education in the Saudi Context. Global Educational Research Journal, 2(4), 50-53.

Altınkaya, H. (1998). Türkiye'de bilgisayar destekli eğitimin gelişimi. Unpublished Master 


\section{Macrothink}

International Journal of Learning and Development

ISSN 2164-4063 2017, Vol. 7, No. 4

Thesis, Gazi Üniversitesi, Ankara, Turkey.

Aşkar, P. (1992). Ilköğretimde bilgisayar: kuram ve uygulamalar. Paper presented at the Symposium of Türkiye'de İlköğretim. Hacettepe Universitesi, Ankara.

Baki, A. (1996). Matematik öğretiminde bilgisayar her şey midir? Hacettepe Üniversitesi Eğitim Fakültesi Dergisi, 12, 135-143.

Baki, A. (2002). Dinamik Geometri Yazılımı Cabri İle Keşfederek Öğrenme, V. Ulusal Fen Bilimleri ve Matematik Eğitimi Kongresi Bildiriler Kitabl, 2(1). 884-891.

Baki, A. (2008). Kuramdan uygulamaya matematik ĕğitimi (4. Basım). Ankara: Harf Eğitim Yayıncılığı.

Baydaş, Ö. Esgice M., Kalafat, Ö., \& Göktaş Y. (2011). Etkileşimli tahtaların öğretim süreçlerine katkıları. Paper presend at the 5th International Computer \& Instructional

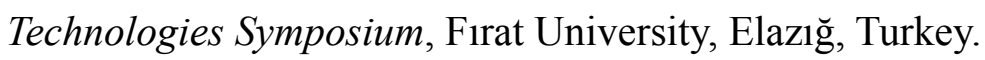

Bayrak, G. (2012). Öğretmenlerin LCD panelli etkileşimli tahtalar hakkındaki hizmet içi eğitim sonrası görüşleri. Unpublished Master Thesis, Atatürk Üniversitesi, Erzurum, Turkey.

Çelik, S., \& Atak, H. (2012). Etkileşimli tahta tutum ölçeğinin geçerlik ve güvenirlik çalışması. Anadolu Journal of Educational Sciences International, 2(2), 43-56

Cradler, J., McNabb, M., Freeman, M., \& Burchett, R. (2001). How does technology influence student learning? Learning \& Leading with Technology, 29(8), 46-56.

Ekici, F. (2008). Akıllı tahta kullanımının ilköğretim öğrencilerin matematik başarılarına etkisi. Unpublished Master Thesis, Marmara Üniversitesi, Istanbul, Turkey.

Ertürk, S. (1982). Eğitimde "program" geliştirme (4. Bask1). Ankara: Yelkentepe Yayınları.

Evertson, C. M., \& Weinstein, C. S. (2006). Handbook of Classroom Management: Research, Practice, and Contemporary Issues. Mahwah, NJ: Lawrence Erlbaum Associates

Jones, K. (2004). Using Interactive Whiteboards in the Teaching and Learning of Mathematics: a research bibliography. Micro Math, 20(2), 5-6.

Kaya, Z. (1998). Bilgisayar ve eğitimde kullanılması. In B. Özer. (Eds.), Çăgdaş Eğitimde Yeni Teknolojiler (pp. 1021-1023). Eskişehir: Anadolu Üniversitesi Yayınları.

Koç, M. (2004). Öğrenme Teorilerinin Etkili Teknoloji Entegrasyonuna Ve Hizmet Öncesi Öğretmen Eğitimine Etkileri: Eleştirel Literatür Taraması. Türk Fen Eğitimi Dergisi, 2(1), 27-32.

Memişoğlu, B. (2005). Matematik öğretiminde bilişim teknolojilerinin kullanımı. Unpublished Master Thesis, Balıkesir Üniversitesi, Balıkesir, Turkey. 


\section{Macrothink}

International Journal of Learning and Development

ISSN 2164-4063 2017, Vol. 7, No. 4

NCTM. (National Council of Teachers of Mathematics). (2008). The role of technology in the teaching and learning of mathematics. A Position of the National Council of Teachers of Mathematics. Retrieved on 28 June 2015 from http://www.nctm.org/Standards-and-Positions/NCTM-Position-Statements/

NCTM. National Council of Teachers of Mathematics. (2000). Principles and Standards for School Mathematics. VA: Reston.

Odabaş1, F. (2012). Bilgisayar destekli eğitim. Bölüm 8. Retrieved on 08 July 2013 from http://w2.anadolu.edu.tr/aos/kitap /IOLTP/2276/unite08.pdf.

Özdemir, S., Yalın, H. İ., \& Sezgin, F. (2008). Eğitim Bilimine Giriş (6. Baskı). Ankara: Nobel Yayıncilik.

Özden, Y. (2002). Sınıf Içinde Öğrenme Öğretme Ortamının Düzenlenmesi. Sınıf Yönetimi. Ankara: Pegem A Yayıncilık.

Sarı, Y., \& Karalar, H. (2007). Bilgi teknolojileri eğitiminde bdö yazılımı kullanma ve uygulama sonuçlarına yönelik bir çalışma. Paper presented at the Akademik Bilişim '07 Conference, Dumlupınar Üniversitesi, Kütahya.

Smith, H. J., Higgins S., Wall K., \& Miller, J. (2005). Interactive whiteboards: boon or bandwagon? a critical review of the literature. Journal of Computer Assisted Learning, 21(2), 91-101. https://doi.org/10.1111/j.1365-2729.2005.00117.x

Yıldızhan, Y. H. (2013). Temel eğitimde akıllı tahtanın matematik başarısına etkisi. Middle Eastern \& African Journal of Educational Research, 5, 110-121.

\section{Copyright Disclaimer}

Copyright for this article is retained by the author(s), with first publication rights granted to the journal.

This is an open-access article distributed under the terms and conditions of the Creative Commons Attribution license (http://creativecommons.org/licenses/by/4.0/). 